\title{
Modeling the growth rate of Listeria innocua influenced by coriander seed essential oil and storage temperature in meat using FTIR
}

\author{
Marzieh Omidi-Mirzaei ${ }^{1}$, Mohammad Hojjati ${ }^{1, *}$, Behrooz Alizadeh Behbahani ${ }^{1}$, Mohammad Noshad ${ }^{1}$ \\ ${ }^{1}$ Department of Food Science and Technology, Faculty of Animal Science and Food Technology, Agricultural Sciences and \\ Natural Resources University of Khuzestan, Mollasani, Iran
}

*Corresponding Author: Mohammad Hojjati, Department of Food Science \& Technology, Faculty of Animal Science and Food Technology, Agricultural Sciences and Natural Resources University of Khuzestan, Postal Code: 63417-73637, Mollasani, Iran. Fax: (+98) 6136522425, Tel: (+98) 6136522101. Emails: hojjati@asnrukh.ac.ir; hojjatifood@gmail.com

Received: 22 June 2020 / Accepted: 29 August 2020 / Published: 07 September 2020

(c) 2020 Codon Publications

\section{OPEN ACCESS CC)(요 ORIGINAL ARTICLE}

\begin{abstract}
The use of natural compounds to preserve food and the application of new tools for monitoring food safety is of great interest. In this study, the growth rate, including the lag time of Listeria innocua in ground lamb as a function of storage temperature $\left(4,10,25\right.$, and $\left.37^{\circ} \mathrm{C}\right)$ influence of the coriander seed essential oil (CEO), as an antimicrobial agent, was modeled. Fourier-transform infrared (FTIR) spectroscopy was used to monitor chemical changes in investigated specimens that may indicate spoilage in ground lamb. Results showed the use of CEO reduced growth rate of $L$. innocua, to approximately 0.0051 (CFU/h) for a sample containing CEO and to 0.042 $(\mathrm{CFU} / \mathrm{h})$ in control samples cultivated at $4^{\circ} \mathrm{C}$. Increasing the cultivation temperature from 4 to $37^{\circ} \mathrm{C}$ led to a 5 -fold increase of the growth rate (0.042 to 0.222 in the control sample) and 28 -fold growth from 0.0051 to 0.147 in a sample containing the CEO. Minimum-recorded temperatures $\left(\mathrm{T}_{\min }\right)$ were -0.57 and $0.60^{\circ} \mathrm{C}$ for the control sample and a sample containing the CEO. The comparison of FTIR spectra of samples during the shelf life indicated that the increased shelf life and bacterial growth results in decreased moisture $\left(1600-1650 \mathrm{~cm}^{-1}\right)$ and protein content in the samples; while the intensity and sharpness of peaks increased in the range $1000-1100 \mathrm{~cm}^{-1}$, indicating the impact of bacterial activity on amounts of amines and amino acids. In conclusion, the CEO increased the L. innocua growth rate lag phase and improved the shelf life of the ground lamb. It is also recommended to use the FTIR to monitor the spoilage in meat.
\end{abstract}

Keywords: coriander essential oil; lamb meat; Listeria innocua; shelf life

\section{Introduction}

At present, foodborne diseases are a rising public health problem. Every year, the consumption of contaminated food with various pathogens causes many human and financial losses in countries around the world (El Sheikha, 2015). Listeria innocua is widely found in the environment, especially in soil and food sources. It is a Grampositive, rod-shaped bacterium that can multiply at low and high temperatures and high salt concentrations. Fresh and frozen raw meat and meat products such as burgers are among foods that can be contaminated by this pathogen and contribute to the transmission of bacteria to consumers (Criado et al., 2019; Gómez et al., 2014). Natural inhibitors such as essential oils for food preservation have now received much attention (Khezerlou et al., 2019; Menezes et al., 2018; Nikolić et al., 2020). Essential oils are secondary products of plant metabolism, aromatic and volatile compounds isolated from various segments of plants, which have a potent antimicrobial, insecticide, and antioxidant ability that has been successful in preventing and treating bacterial infections (Azhdarzadeh et al., 2018; 
Foltinova et al., 2019; Khezerlou et al., 2019). Coriander (Coriandrum sativum L.) is an annual plant belonging to the Apiaceae family that probably originated from the eastern Mediterranean and spread to the world as an old spice (Laribi et al., 2015). The herb and seeds of coriander include bioactive components, which are used in the pharmaceutical industries (Omidbaigi et al., 2009). Coriander seed is extensively used in traditional Iranian medicine for the treatment of various disorders (Nejad Ebrahimi et al., 2010) as well as in several food products like pickles, curry powder, sausages, meat, confectionery, and bakery as a condiment (Laribi et al., 2015; Nejad Ebrahimi et al., 2010). Šojić et al. (2019) evaluated the use of $\mathrm{CEO}$ as a natural food additive on cooked pork sausage quality. They observed that the use of CEO improved the oxidative and microbial stability of cooked pork sausages during refrigerated storage. Recently, guar gum, including extracts of some culinary spices like coriander seed was used as edible coating to prolong lemon's shelf life and showed that treated lemon had better physicochemical, biochemical, and microbiological attributes than controls (Naeem et al., 2019).

To date, the use of new techniques and tools instead of traditional methods for identifying foodborne microorganisms and monitoring food safety has increased for various reasons (El Sheikha et al., 2018). Predictive microbiology is applied to enhance and use mathematical models to predict the response of microorganisms to factors and measured under controlled and defined conditions (Noori et al., 2014). Predictive models are significantly crucial in determining microbial behavior factors in the farm-to-consumer food chain to decide the shelf life of perishable foods. Many efforts have been made to assess risk and manage the risk of widespread diseases due to microbial pathogens (Costa et al., 2019; Don et al., 2018). Different levels of models are used in the predictive microbiology of foods. First-level models deal with microbial changes over time. In these models, changes in numbers of bacteria over time are calculated under specific environmental conditions, but in the second-level model, changes in initial model parameters are evaluated under the influence of ecological factors (Juneja et al., 2019; Kakagianni and Koutsoumanis, 2019; Yoon et al., 2019). In other words, the models describe the response of one or more parameters of the initial model such as bacterial growth lag phase time due to changes in environmental conditions such as temperature (Lianou et al., 2018; Menezes et al., 2018; Mishra et al., 2017; Sommers et al., 2018). Fourier-transform infrared (FTIR) spectroscopy is a rapid, advanced, simple, environmentally friendly, and reliable analytical technique that has recently been used in quality control and market management of various food products (Xu et al., 2018; Yasmin et al., 2019). Therefore, the present study aims to dynamically model the growth behavior of $L$. innocua as a function of storage temperature in ground lamb containing CEO using FTIR to monitor chemical changes for indicating the spoilage.

\section{Material and Methods}

\section{Bacterial strain and inoculum preparation}

Listeria innocua ATCC 33090 was obtained from Mashhad University of Medical Sciences (Mashhad, Iran). It was cultured in Müller-Hinton (MH) broth (Difco, Detroit, MI, USA) in sterile falcon tubes (Becton Dickinson, Falcon ${ }^{\mathrm{rw}}$, Franklin Lakes, NJ, USA) and incubated at $37^{\circ} \mathrm{C}$ for $24 \mathrm{~h}$, centrifuged at $9000 \mathrm{rpm}$ at $7^{\circ} \mathrm{C}$ for $5 \mathrm{~min}$. To rinse the bacterial sediment, 4 to $5 \mathrm{~mL}$ of physiological saline was added, vortexed, and re-centrifuged. Initial bacterial suspension of $10^{8} \mathrm{CFU} / \mathrm{mL}$ has been prepared using McFarland 0.5 Turbidity Standard, and it was diluted up to a final, desired concentration of $10^{4} \mathrm{CFU} / \mathrm{g}$ (McNamee et al., 2010; Rasooli et al., 2006). During the incubation period, $1 \mathrm{~g}$ was taken from the meat sample every $24 \mathrm{~h}$ and serial dilutions were made in physiological saline, inoculated on $\mathrm{MH}$ agar with $6.5 \% \mathrm{NaCl}$ (Merck, Darmstadt, Germany) and incubated for the determination of the exact number of L. innocua.

\section{Meat samples}

Fresh ground lamb (10.48\% fat, $17.26 \%$ protein, and $1.23 \%$ ash) was purchased from the local retail store and transferred to the laboratory in the shortest time following hygienic conditions in a plastic bag and rubber dry icebox. Compositional percentage of lamb meat such as fat, protein, and ash were determined according to the Official Methods of Analysis of Association of Official Analytical Chemists (AOAC, 2005). Coriander seed essential oil (CEO) was bought from Tabib Daru Co, Iran. For every $5 \mathrm{~g}$ of ground lamb, $0.075 \mathrm{~g}$ of sterile CEO (passed through a 0.22 syringe filter) and the microbial suspension was added and mixed well with the ground lamb, so the final number of bacteria was $10^{4} \mathrm{CFU} / \mathrm{g}$. The ground lamb samples were separated and placed in sterile plastic bags and stored at $4,10,25$, and $37^{\circ} \mathrm{C}$ for 8 days, and bacterial counts were monitored on days $0,2,4,6$, and 8 of samples. At each of the examined temperatures, a ground lamb sample without CEO that was sterilized with plasma (APLM-SP-YB-D1KW, ATV Electronic Technology Co., Suzhou, China) was used as the control sample.

\section{FTIR}

The FTIR spectrophotometer (Thermo Nicolet, Madison, WI, USA) at ambient temperature was used 
for $1000-2000 \mathrm{~cm}^{-1}$ with a resolution of $4 \mathrm{~cm}^{-1}$ to obtain spectral information of ground lamb. For this purpose, meat samples were placed directly on the plate to completely cover the Zinc selenide crystal sensor without any air bubble remaining between the sample and the top of the crystal and spectra of control and sample containing CEO were evaluated (Akhtar et al., 2018; Papadopoulou et al., 2011).

\section{Evaluation of growth parameters}

Three growth curves, representing three replications at each incubation temperature $\left(4,10,25\right.$, and $\left.37^{\circ} \mathrm{C}\right)$, were obtained in the present study. Two replications of each temperature were used for the analysis of kinetic parameters, including specific growth rates (ln $\mathrm{CFU} / \mathrm{g} \mathrm{h}^{-1}$, $\left.\mu_{\max }\right)$ and lag time $(\mathrm{l}, \mathrm{h})$, and the remaining replications were evaluated for the model validation (equations 1-3) (Huang, 2014). To fit data, the laboratory data on the growth of L. innocua were first converted as $\log (\mathrm{CFU} / \mathrm{g})$. The reduced Huang equation was then utilized for the initial modeling of L. innocua growth in control and a sample containing 1.5\% CEO. MATLAB software (The Mathworks Inc., Natick, MA, USA, version R2016a) was used to fit the data and obtain growth parameters such as maximum specific growth rate and duration of lag phase. The Suboptimal Huang Square-Root equation was used to examine the dependence of the maximum specific growth rate on temperature. Equation (4) was also used to investigate the effect of temperature on the lag time of bacterial growth (Huang, 2014; Huang et al., 2012).

$$
\begin{array}{cc}
\mathrm{Y}=\mathrm{Y}_{0}+\mu_{\max }\left\{\mathrm{t}+\frac{1}{4} \ln \left[\frac{1+\mathrm{e}^{-4(\mathrm{t}-\lambda)}}{1+\mathrm{e}^{4 \lambda}}\right]\right\} & \\
\mathrm{Y}=\mathrm{Y}_{0}+\mathrm{Y}_{\max }-\ln \left\{\mathrm{e}^{\mathrm{Y}_{0}}+\left[\mathrm{e}^{\mathrm{Y}_{\max }}-\mathrm{e}^{\mathrm{Y}_{0}}\right] \mathrm{e}^{-\mu_{\max } \mathrm{B}(\mathrm{t})}\right\} & \text { Equation (1) } \\
\mathrm{B}(\mathrm{t})=\mathrm{t}+\frac{1}{4} \ln \left(\frac{1+\mathrm{e}^{-4(\mathrm{t}-\lambda)}}{1+\mathrm{e}^{4 \lambda}}\right) & \text { Equation (2) } \\
\sqrt{\mu_{\max }}=\mathrm{a}\left(\mathrm{T}-\mathrm{T}_{\min }\right)^{0.75} & \text { Equation (3) } \\
\lambda=\alpha+\beta \times \ln \left(\mu_{\max }\right) & \text { Equation (4) }
\end{array}
$$

Here, initial bacterial concentration $=\mathrm{Y}_{0}$; lag time $(\mathrm{h})=\lambda$; specific growth rates $\left(\log \mathrm{CFU} / \mathrm{g} \mathrm{h}^{-1}\right)=\mu_{\max }$; maximum cell $=\mathrm{Y}_{\max }$; real-time number of bacterial $(\log (\mathrm{CFU} / \mathrm{g}))=\mathrm{Y}$; regression coefficients $=\alpha, \beta$, $\mathrm{a}$.

\section{Statistical analysis}

The statistical parameters, namely the Root Mean Square Error (RMSE), the sum of squared estimate of errors (SSE), and correlation coefficient $\left(\mathrm{R}^{2}\right)$, were used to compare the efficiency of primary and secondary models and validate the model (Juneja et al., 2019; Mishra et al., 2017). In that $k$ is the number of experimental data, $m$ is the number of model parameters, $o_{\exp }$ are the experimental values of concentration of microbial cells, $o_{\text {pre }}$ are the prediction values of concentration of microbial cells, and $\bar{o}$ is the mean value of concentration of microbial cells.

$$
\begin{aligned}
\mathrm{R}^{2} & =\frac{\sum\left(\mathrm{o}_{\text {pre }}-\overline{\mathrm{o}}\right)^{2}}{\sum\left(\mathrm{o}_{\text {exp }}-\overline{\mathrm{o}}\right)^{2}} \\
\mathrm{RMSE} & =\sqrt{\frac{\sum\left(\mathrm{o}_{\exp }-\mathrm{o}_{\mathrm{pre}}\right)^{2}}{\mathrm{k}-\mathrm{m}}} \\
\mathrm{SSE} & =\sum\left(\mathrm{o}_{\mathrm{pre}}-\mathrm{o}_{\text {exp }}\right)^{2}
\end{aligned}
$$

\section{Results and Discussion}

First, the reduced Huang model was fitted on the obtained laboratory data from the growth of L. innocua in raw ground lamb, and model parameters (maximum specific growth rate and duration of lag phase) were examined. It should be noted that $7 \log C F U / g$ of L. innocua was used as an upper limit number, that is, an indicator for the evaluation of the shelf life of investigated specimen (Sommers et al., 2018). As shown in Figure 1, the lag phases shortened with increasing the incubation temperature. Figure 1 shows a concentration of $7 \log C F U / g$ of L. innocua in the control sample reached after 3 days of incubation at $4{ }^{\circ} \mathrm{C}$, and the same number of L. innocua was reached in a sample containing 1.5\% CEO after 25 days of incubation at the same temperature. At $10^{\circ} \mathrm{C}$, the bacterial population in a CEO sample reached $7 \log C F U / g$ after 8 days of incubation, and thus the shelf life of samples increased by 6 days compared to the control sample.

As observed in Figure 1, the antimicrobial activity of CEO greatly impacts growth parameters. According to results (Table 1), increasing the temperature from 4 to $37^{\circ} \mathrm{C}$ led to 5 -fold increased growth rate $(0.042$ to 0.222 in the control sample) and 28-fold increased growth from 0.0051 to 0.147 in a sample containing CEO. Furthermore, increasing the temperature from 4 to $37^{\circ} \mathrm{C}$ led to a 20 -fold decrease in lag time (from 18 to $0.9 \mathrm{~h}$ ) in the control sample and a 65-fold decrease (from 90 to $1.38 \mathrm{~h}$ ) in a sample containing seed CEO.

Table 1 presents the mean values of parameters a and $\mathrm{T}_{\min }$ for L. innocua in the control sample and CEO sample. Minimum-recorded temperatures $\left(\mathrm{T}_{\min }\right)$ were -0.57 and $0.60^{\circ} \mathrm{C}$ for the control and CEO sample, 

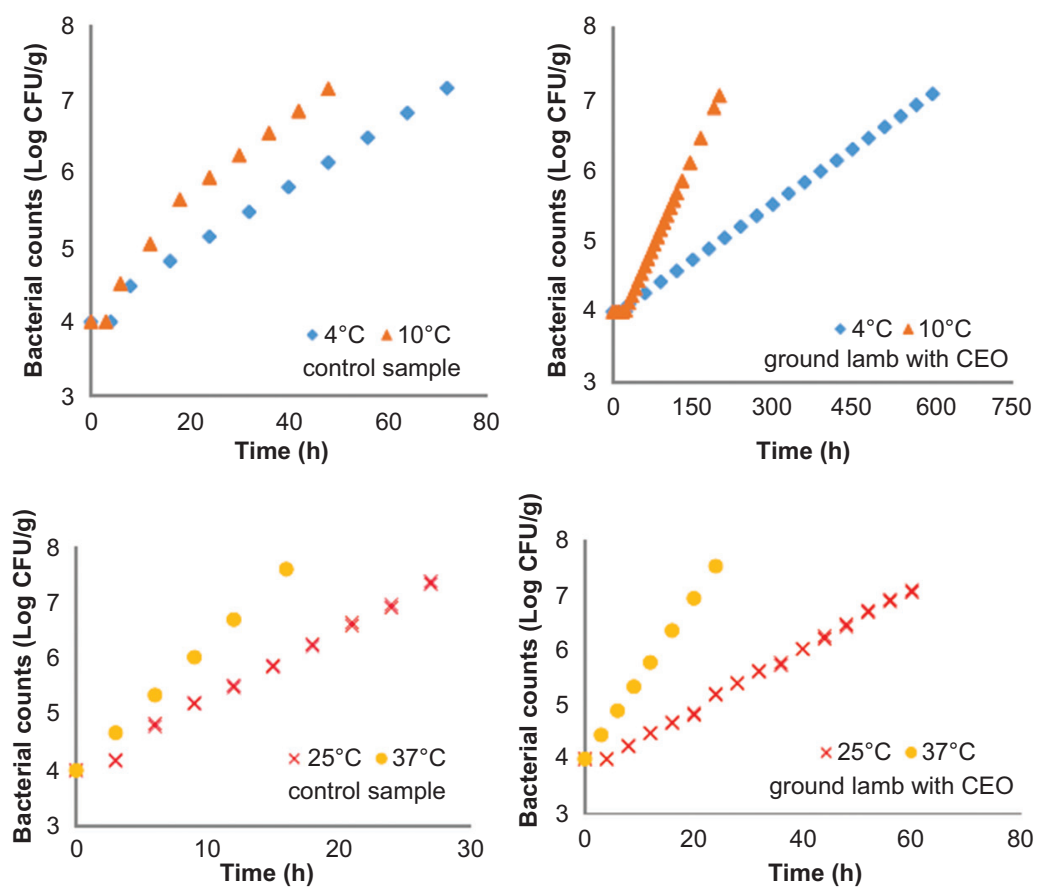

Figure 1. Effect of CEO and storage temperatures on the growth rate of $L$. innocua in ground lamb.

Table 1. Statistical parameters for $L$. innocua growth rate in ground lamb samples.

\begin{tabular}{|c|c|c|c|c|c|}
\hline & $a^{*}$ & $\mathrm{~T} \min$ & $\mathbf{R}^{2}$ & RMSE & SSE \\
\hline Ground lamb without CEO (Control) & $0.02 \pm 0.01$ & $-0.57 \pm 0.10$ & 0.97 & 0.21 & 0.0441 \\
\hline Ground lamb with CEO & $0.023 \pm 0.003$ & $0.6 \pm 0.1$ & 0.94 & 0.27 & 0.0729 \\
\hline
\end{tabular}

respectively. Besides, Table 1 presents the obtained statistical parameters (RMSE, SSE, and $\mathrm{R}^{2}$ ) from the fitting model to the laboratory data. Statistical indices indicated high accuracy of the model in the data prediction so that $\mathrm{R}^{2}$ value was $97 \%$ for the control sample, and $94 \%$ for a sample containing $1.5 \%$ CEO. The RMSE values were 0.21 for the control and $1.5 \%$ for the CEO sample, respectively.

Figure 2 shows the most important spectral peaks of FTIR for the ground lamb. Based on the obtained data, the FTIR spectrum can be divided into four categories: (1) $1600-1650 \mathrm{~cm}^{-1}$, (2) $1500-1550 \mathrm{~cm}^{-1}$, (3) 1200$1350 \mathrm{~cm}^{-1}$, and (4) $1000-1100 \mathrm{~cm}^{-1}$. Wave range of $1600-1650 \mathrm{~cm}^{-1}$ was caused by hydroxyl groups $(\mathrm{OH})$, moisture, and amide bond $I$ in protein. The peaks in the wave range of $1500-1550 \mathrm{~cm}^{-1}$ indicate the tensile of $\mathrm{C}-\mathrm{N}$ bonds of amide groups II in the sample protein. The peak in the wave range $1220-1800 \mathrm{~cm}^{-1}$ indicates the presence of a tensile $\mathrm{C}=\mathrm{O}$ bond (first type amide) in the

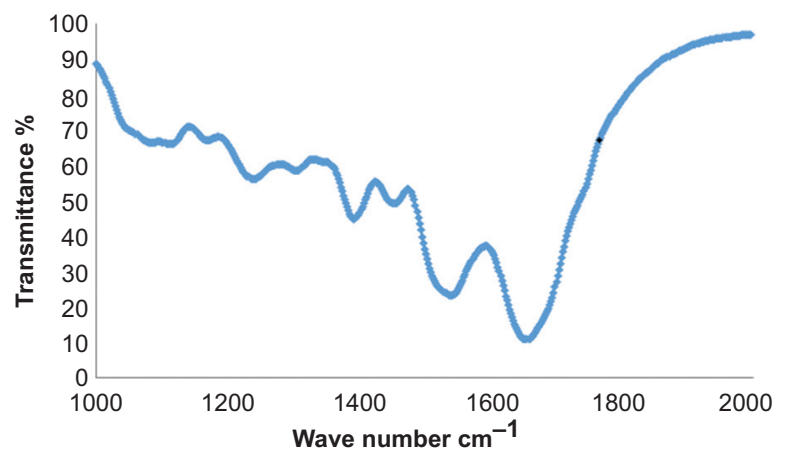

Figure 2. FTIR spectra of ground lamb.

sample. Furthermore, the peak in 1200-1350 indicates the presence of a tensile $\mathrm{C}-\mathrm{N}$ bond of amine groups in the sample structure. The observed peak in 1000-1100 $\mathrm{cm}^{-1}$ is related to free amino acids and amines in the sample structure (Papadopoulou et al., 2011). 
According to results, the use of CEO reduced the growth rate of L. innocua, so no bacterial growth was seen in samples containing 1.5\% CEO oil during the first $90 \mathrm{~h}$ of incubation. However, increasing the incubation temperature increased bacterial growth rates in control samples, but CEO reduced growth rates at all incubation temperatures. Thus, the CEO increased shelf life of the ground lamb, from 3 days for the control sample to 25 days for the samples with $\mathrm{CEO}$ incubated at $4^{\circ} \mathrm{C}$. And the shelf life was $27 \mathrm{~h}$ for the controls and $60 \mathrm{~h}$ for the CEO samples incubated at $25^{\circ} \mathrm{C}$. The shelf life of samples incubated at $37^{\circ} \mathrm{C}$ was $16 \mathrm{~h}$ for the control and $24 \mathrm{~h}$ for CEO samples. Chouliara et al. (2007) investigated the impact of using orange essential oils on the shelf life of fresh chicken incubated at $4{ }^{\circ} \mathrm{C}$. The results of this study indicated that adding $1 \%$ essential oil completely prevented the bacterial growth of lactic acid bacteria for 12 days and increased the shelf life of samples up to 16 days, while the lactic acid bacteria reached a concentration of $7 \log C F U / g$ after 9 days in control samples. Mexis et al. (2009) examined the impact of the addition of $0.1 \%$ essential oil on tarama salad shelf life that was kept at $4{ }^{\circ} \mathrm{C}$ and indicated that the concentration of lactic acid bacteria reached $6.45 \log \mathrm{CFU} / \mathrm{g}$ in the control sample after 24 days of storage, while it reached 5.95 in the sample containing essential oil after 40 days of storage. Sant'Ana et al. (2012) examined the shelf life of packed minimally processed lettuce at storage temperatures of 7 to $30^{\circ} \mathrm{C}$ and reported $\mu$ value between $0.02 \pm 0.0001$ (for $7^{\circ} \mathrm{C}$ ) and $0.02+0.22$ (for $30^{\circ} \mathrm{C}$ ) for L. innocua. In addition, $\lambda$ value was found between $59.4+12.7\left(7^{\circ} \mathrm{C}\right)$ and $2.4+0.8$
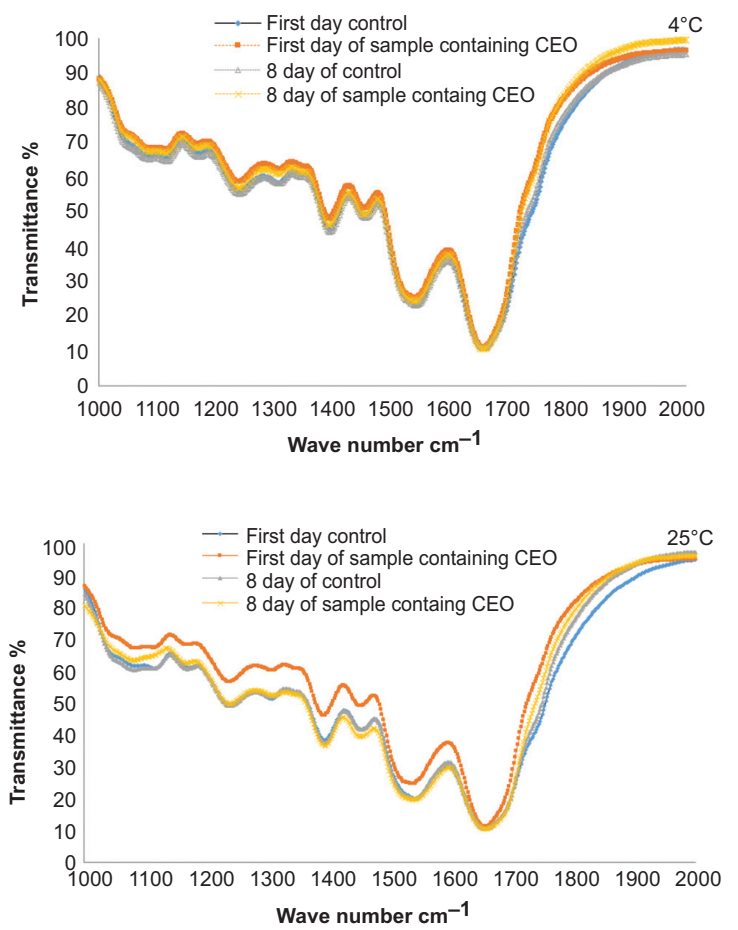

$\left(30^{\circ} \mathrm{C}\right)$ for L. innocua. Kaklan (2019) evaluated the antimicrobial effect of probiotic lactic acid bacteria against Staphylococcus aureus in white cheese. The result of this study showed the number of $S$. aureus has decreased by approximately $5 \log$ units at the end of the storage time. Li et al. (2020) evaluated the kinetic models (Huang, Baranyi, and Reparameterized Gompertz model) to describe the growth of Pseudomonas spp. in Agaricus bisporus fruiting bodies. Results of this study showed the Reparameterized Gompertz model was a better fit than the Huang and Baranyi models to describe the growth of Pseudomonas spp., and had the lowest mean square error (MSE) and sum of squared errors (SSE) values, ranging $0.012-0.291$ and $0.059-1.783$, respectively.

The minimum temperature that supported the growth of L. innocua was about $3^{\circ} \mathrm{C}$ (Junttila et al., 1988). The minimum temperature $\left(\mathrm{T}_{\min }\right)$ was often below the minimum storage temperature for bacterial growth. Our study showed that $\mathrm{T}_{\min }$ values for L. innocua for the control sample and CEO samples were -0.57 and $0.60^{\circ} \mathrm{C}$, respectively. Slope parameters (b) were 0.020 and 0.023 for the control sample and a sample containing CEO. The comparison of FTIR spectra of samples during the shelf life indicated that the increased shelf life and bacterial growth decreased moisture (1600-1650 $\mathrm{cm}^{-1}$ ) and protein content in the samples, while the intensity and sharpness of peaks increased in $1000-1100 \mathrm{~cm}^{-1}$, indicating the impact of bacterial activity on amounts of amines and amino acids (Figure 3). The proteolysis process due to the bacterial activity during the shelf life was the
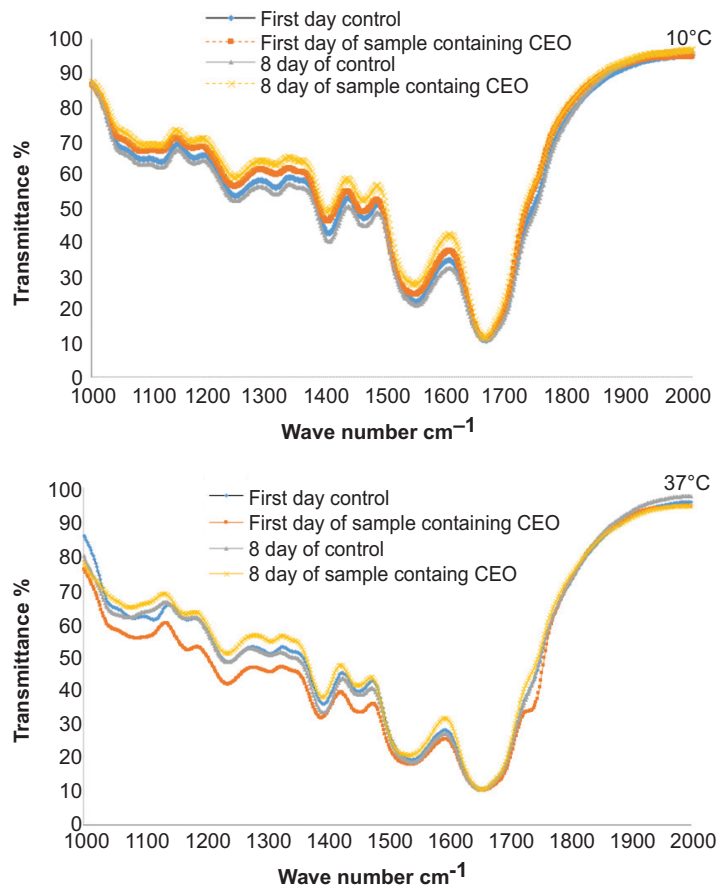

Figure 3. Effect of CEO and storage temperatures on the FTIR spectra of ground lamb. 
most critical reason for changes in amounts and intensity of peaks in the FTIR spectrum (Argyri et al., 2010). Furthermore, the comparison of the control sample and a sample containing the CEO indicated the lower rates of changes in intensity and sharpness of peaks in samples containing $\mathrm{CEO}$ at the same temperature and duration compared to the first day, indicating the inhibitory effect of CEO on the L. innocua activity.

\section{Conclusions}

In conclusion, the reduced Huang model can be used with high accuracy $\left(R^{2}>0.94\right)$ to predict the growth rate of L. innocua in ground lamb. The addition of CEO in meat samples increased delayed phases of samples, so at $10^{\circ} \mathrm{C}$, the bacterial population in a CEO sample reached an upper limit number $7 \log \mathrm{CFU} / \mathrm{g}$ after 8 days, and thus the shelf life of samples increased by 6 days compared to the control sample. While increasing the temperature from 4 to $37^{\circ} \mathrm{C}$ led to a 20 -fold decrease in lag time (from 18 to $0.9 \mathrm{~h}$ ) in the control sample and a 65 -fold decrease (from 90 to $1.38 \mathrm{~h}$ ) in a sample containing the CEO. Furthermore, the comparison of FTIR spectra of the control sample and a sample containing the CEO indicated the lower rates of changes in intensity and sharpness of peaks in samples containing the CEO at the same temperature and duration compared to the first day, indicating the inhibitory effect of CEO on the L. innocua activity. According to results, the CEO can be used as a natural antimicrobial in various meat applications in the food industry to extend the shelf life. Also, FTIR can be used to monitor chemical changes in meat, which may represent the spoilage. It is also suggested as a suitable tool to predict the shelf life of meat products at different storage temperatures.

\section{Acknowledgments}

The authors wish to thank the Agricultural Sciences and Natural Resources University of Khuzestan for supporting this research.

\section{Conflict of interest}

There is no conflict of interest.

\section{References}

Akhtar, H.M.S., Riaz, A., Hamed, Y.S., Abdin, M., Chen, G., Wan, P. and Zeng, X., 2018. Production and characterization of CMCbased antioxidant and antimicrobial films enriched with chickpea hull polysaccharides. International Journal of Biological
Macromolecules 118: 469-477. https://doi.org/10.1016/j. ijbiomac.2018.06.090

AOAC, 2005. Official methods of analysis of the Association of Analytical Chemists International (18th ed.). USA Official methods, Gathersburg, MD.

Argyri, A.A., Panagou, E.Z., Tarantilis, P., Polysiou, M. and Nychas, G.-J., 2010. Rapid qualitative and quantitative detection of beef fillets spoilage based on Fourier transform infrared spectroscopy data and artificial neural networks. Sensors and Actuators B: Chemical 145(1): 146-154. https://doi. org/10.1016/j.snb.2009.11.052

Azhdarzadeh, F., Hojjati, M. and Tahmuzi Didehban, S., 2018. Chemical composition and antimicrobial activity of Pelargonium roseum essential oil from southwest of Iran. Journal of Food and Bioprocess Engineering 1(1): 33-38.

Chouliara, E., Karatapanis, A., Savvaidis, I. and Kontominas, M., 2007. Combined effect of oregano essential oil and modified atmosphere packaging on shelf-life extension of fresh chicken breast meat, stored at $4^{\circ} \mathrm{C}$. Food Microbiology 24(6): 607-617. https://doi.org/10.1016/j.fm.2006.12.005

Costa, J.C.C.P., Bover-Cid, S., Bolívar, A., Zurera, G. and Pérez-Rodríguez, F., 2019. Modelling the interaction of the sakacin-producing Lactobacillus sakei CTC494 and Listeria monocytogenes in filleted gilthead sea bream (Sparus aurata) under modified atmosphere packaging at isothermal and non-isothermal conditions. International Journal of Food Microbiology 297: 72-84. https://doi.org/10.1016/j. ijfoodmicro.2019.03.002

Criado, P., Fraschini, C., Jamshidian, M., Salmieri, S., Desjardins, N., Sahraoui, A. and Lacroix, M., 2019. Effect of cellulose nanocrystals on thyme essential oil release from alginate beads: study of antimicrobial activity against Listeria innocua and ground meat shelf life in combination with gamma irradiation. Cellulose 26(9): 5247-5265. https://doi.org/10.1007/s10570-019-02481-2

Don, S., Xavier, K.M., Devi, S.T., Nayak, B.B. and Kannuchamy, N., 2018. Identification of potential spoilage bacteria in farmed shrimp (Litopenaeus vannamei): application of relative rate of spoilage models in shelf life-prediction. LWT - Food Science and Technology 97: 295-301. https://doi.org/10.1016/j.lwt.2018.07.006

El Sheikha, A.F., 2015. Food safety issues in Saudi Arabia. Nutrition and Food Technology 1(1): 1-4. https://doi. org/10.16966/2470-6086.103

El Sheikha, A.F., Levin, R.E. and Xu, J., 2018. Molecular techniques in food biology: safety, biotechnology, authenticity and traceability. John Wiley \& Sons Ltd., Chichester, UK. https://doi. org/10.1002/9781119374.633

Foltinova, D., Tancinova, D. and Cisarova, M., 2019. Inhibitory effect of essential oils on the growth of Geotricum candidum. Journal of Microbiology, Biotechnology and Food Sciences 9: 380-384. https://doi.org/10.15414/ jmbfs.2019.9.special.380-384

Gómez, D., Azón, E., Marco, N., Carramiñana, J.J., Rota, C., Ariño, A. and Yangüela, J., 2014. Antimicrobial resistance of Listeria monocytogenes and Listeria innocua from meat products and meat-processing environment. Food Microbiology 42: 61-65. https://doi.org/10.1016/j.fm.2014.02.017 
Huang, L., 2014. IPMP 2013-a comprehensive data analysis tool for predictive microbiology. International Journal of Food Microbiology 171: 100-107. https://doi.org/10.1016/j. ijfoodmicro.2013.11.019

Huang, L., Tu, S.I., Phillips, J. and Fratamico, P., 2012. Mathematical modeling of growth of non-O157 Shiga toxin-producing Escherichia coli in raw ground beef. Journal of Food Science 77(4): M217-M225. https://doi.org/10.1111/j.1750-3841.2012.02647.x

Juneja, V.K., Golden, C.E., Mishra, A., Harrison, M.A., Mohr, T. and Silverman, M., 2019. Predictive model for growth of Bacillus cereus during cooling of cooked rice. International Journal of Food Microbiology 290: 49-58. https://doi.org/10.1016/j. ijfoodmicro.2018.09.023

Junttila, J.R., Niemelä, S. and Hirn, J., 1988. Minimum growth temperatures of Listeria monocytogenes and non-haemolytic listeria. Journal of Applied Bacteriology 65(4): 321-327. https://doi. org/10.1111/j.1365-2672.1988.tb01898.x

Kakagianni, M. and Koutsoumanis, K.P., 2019. Assessment of Escherichia coli O157: H7 growth in ground beef in the Greek chill chain. Food Research International 123: 590-600. https:// doi.org/10.1016/j.foodres.2019.05.033

Kaklan, S., 2019. Predicting the antimicrobial effect of probiotic lactic acid bacteria against Staphylococcus aureus in white cheeses, using Fourier series modeling method. Journal of Food Safety 40(1): e12724. https://doi.org/10.1111/jfs.12724.

Khezerlou, A., Azizi-Lalabadi, M., Mousavi, M., and Ehsani, A, 2019. Incorporation of essential oils with antibiotic properties in edible packaging films. Journal of Food and Bioprocess Engineering 2(1): 77-84.

Laribi, B., Kouki, K., M'Hamdi, M. and Bettaieb, T., 2015. Coriander (Coriandrum sativum L.) and its bioactive constituents. Fitoterapia 103: 9-26. https://doi.org/10.1016/j. fitote.2015.03.012

Li, J., Wei, Q., Huang, L., Fang, T., Chen, B. and Jiang, Y., 2020. Mathematical modeling Pseudomonas spp. growth and microflora composition variation in Agricus bisporus fruiting bodies during chilled storage. Postharvest Biology and Technology 163: 111-144. https://doi.org/10.1016/j.postharvbio.2020.111144.

Lianou, A., Moschonas, G., Nychas, G.-J.E. and Panagou, E.Z., 2018. Growth of Listeria monocytogenes in pasteurized vanilla cream pudding as affected by storage temperature and the presence of cinnamon extract. Food Research International 106: 1114-1122. https://doi.org/10.1016/j.foodres.2017.11.027

McNamee, C., Noci, F., Cronin, D., Lyng, J., Morgan, D., and Scannell, A., 2010. PEF based hurdle strategy to control Pichia fermentans, Listeria innocua and Escherichia coli k12 in orange juice. International Journal of Food Microbiology 138(1-2): 13-18. https://doi.org/10.1016/j.ijfoodmicro.2009.12.001

Menezes, N.M.C., Martins, W.F., Longhi, D.A. and de Aragão, G.M.F., 2018. Modeling the effect of oregano essential oil on shelf-life extension of vacuum-packed cooked sliced ham. Meat Science 139: 113-119. https://doi.org/10.1016/j. meatsci.2018.01.017

Mexis, S., Chouliara, E. and Kontominas, M., 2009. Combined effect of an $\mathrm{O} 2$ absorber and oregano essential oil on shelf-life extension of Greek cod roe paste (tarama salad) stored at $4^{\circ} \mathrm{C}$.
Innovative Food Science \& Emerging Technologies 10(4): 572579. https://doi.org/10.1016/j.ifset.2009.04.005

Mishra, A., Guo, M., Buchanan, R.L., Schaffner, D.W. and Pradhan, A.K., 2017. Development of growth and survival models for Salmonella and Listeria monocytogenes during non-isothermal time-temperature profiles in leafy greens. Food Control 71: 32-41. https://doi.org/10.1016/j.foodcont.2016.06.009

Naeem, A., Abbas, T., Ali, T.M. and Hasnain, A., 2019. Application of guar gum-based edible coatings supplemented with spice extracts to extend post-harvest shelf life of lemon (Citrus limon). Quality Assurance and Safety of Crops \& Foods 11(3): 241-250. https://doi.org/10.3920/QAS2018.1310

Nejad Ebrahimi, S., Hadian, J. and Ranjbar, H., 2010. Essential oil compositions of different accessions of Coriandrum sativum L. from Iran. Natural Products Research 24(14): 1287-1294. https://doi.org/10.1080/14786410903132316

Nikolić, A., Dordević, V., Parunović, N., Stefanović, S., Đurić, S., Babić, J., and Vasilev, D. 2020. Can polyphenols be used as natural preservatives in fermented sausages? Acta Veterinaria 70(2): 219-237. https://doi.org/10.2478/acve-2020-0016

Noori, Z., Khanzadi, S., Jamshidi, A. and Seifi, H.A., 2014. Modeling the effects of Bunium persicum (Black Zira) essential oil, pH, inoculums size and temperature on the growth of Listeria monocytogenes. Iranian Journal of Veterinary Research 15(3): 272278. https://doi.org/10.22099/IJVR.2014.2539

Omidbaigi, R., Rahimi, S. and Naghavi, M.R., 2009. Evaluation of molecular and essential oil diversity of coriander (Coriandrum sativum L.) landraces from Iran. Journal of Essential Oil Bearing Plants 12(1): 46-54. https://doi.org/10.1080/09720 60X.2009.10643690

Papadopoulou, O., Panagou, E., Tassou, C. and Nychas, G.-J., 2011. Contribution of Fourier transform infrared (FTIR) spectroscopy data on the quantitative determination of minced pork meat spoilage. Food Research International 44(10): 3264-3271. https://doi.org/10.1016/j.foodres.2011.09.012

Rasooli, I., Rezaei, M.B. and Allameh, A., 2006. Ultrastructural studies on antimicrobial efficacy of thyme essential oils on Listeria monocytogenes. International Journal of Infectious Diseases 10(3): 236-241. https://doi.org/10.1016/j.ijid.2005.05.006

Sant'Ana, A.S., Franco, B.D. and Schaffner, D.W., 2012. Modeling the growth rate and lag time of different strains of Salmonella enterica and Listeria monocytogenes in ready-to-eat lettuce. Food Microbiology 30(1): 267-273. https://doi.org/10.1016/j. fm.2011.11.003

Šojić, B., Pavlić, B., Ikonić, P., Tomović, V., Ikonić, B., Zeković, Z., Kocić-Tanackov, S., Jokanović, M., Škaljac, S. and Ivić, M., 2019. Coriander essential oil as natural food additive improves quality and safety of cooked pork sausages with different nitrite levels. Meat Science 157: 107879. https://doi.org/10.1016/j. meatsci.2019.107879

Sommers, C., Huang, C.-Y., Sheen, L.-Y., Sheen, S. and Huang, L., 2018. Growth modeling of uropathogenic Escherichia coli in ground chicken meat. Food Control 86: 397-402. https://doi. org/10.1016/j.foodcont.2017.12.007

Xu, Y., Hassan, M.M., Kutsanedzie, F.Y.H., Li, H.H., and Chen, Q.S. 2018. Evaluation of extra-virgin olive oil adulteration using FTIR 
spectroscopy combined with multivariate algorithms. Quality Assurance and Safety of Crops \& Foods 10(4): 411-421. https:// doi.org/10.3920/QAS2018.1330

Yasmin, J., Ahmed, M.R., Lohumi, S., Wakholi, C., Lee, H., Mo, C., and Cho, B.K. 2019. Rapid authentication measurement of cinnamon powder using FT-NIR and FT-IR spectroscopic techniques. Quality Assurance and Safety of Crops \& Foods 11(3): 257-267. https://doi.org/10.3920/QAS2018.1318

Yoon, J.-H., Han, A., Paek, J. and Lee, S.-Y., 2019. Evaluation of non-isothermal inactivation on survivals of pathogenic bacteria by predictive models. LWT - Food Science and Technology 101: 366-373. https://doi.org/10.1016/j.lwt.2018.11.023 